\title{
Accounting in Organizational Change: \\ a Practice Theory Approach
}

PAOLA TREVISAN

pao.trevisan@gmail.com

Ca' Foscari University of Venice

The aim of this project is to gain a better understanding of the role of accounting practices within complex processes of organizational change.

In the last couple of decades accounting scholars have shown an increasing interest in studying how practices of calculation of various types are involved in the transformation of organizational structures and identities. Accordingly, several studies on accounting have adopted interpretive approaches and focused on the role of institutional and social context in which accounting practices evolve. These studies have mainly investigated cases of accounting change, such as the introduction of new ERP systems (Quattrone and Hopper, 2005), the adoption of ABC techniques (Soin et al., 2002) and of per- 
formance management systems (Masquefa et al., 2016). Despite the interesting insights that these studies provide, showing how accounting systems are shaped by the context, there is still a lack of understanding of the interdependence between accounting and organization. In fact, if on one hand accounting is shaped by the context, on the other hand the context itself is object of changes which are planned on the basis of the information provided by the accounting system, that the context contributes to shape. For this reason, this study aims at investigate further this interrelationship by analyzing it in a context of radical organizational change.

The specific questions this study will address are:

How do accounting practices change to meet the need for organizational change? Who has the power to decide what the new accounting knowledge should contain, and how it should be fabricated? Who interprets accounting knowledge and what uses they make in the decision making process for organizational change?

How the changing organization influences the new accounting system and approach? How 
does resistance to organizational change assess accounting knowledge? How does the new accounting knowledge contribute to transform the picture of organizational reality and thus to support the discourse of organizational change?

This research is designed as an interpretive study based on an intensive fieldwork, where accounting practices are analysed in the context in which they operate and evolve. The organizational context that provides the basis for such study is a fashion company which is involved in a profound transformation process. The field, thus, offers an interesting case for the analysis of the dynamics and the interrelationship between accounting and organization in a changing environment.

The theoretical framework draws on Bourdieu's works, in particular around the notion of 'habitus' - which constitutes the basis of his practice theory-, 'field' and 'capital', as well as from the works of other scholars who applied practice theory in management studies, in particular in the field of strategy (Whittington, 2006). According to Malsch, Gendron and Grazzini (2011), who reviewed the influence of 
Bourdieu's work in accounting research, the majority of the Bourdieusian studies in accounting do not mobilize his core concepts of field, capital and habitus holistically. In particular, they say, the concept of habitus is infrequently used in examining micro processes ensuing from the creation and reproduction of power relations in society. This project will thus bring an innovative translation of Bourdieu's theoretical framework in accounting research, with a particular emphasis on the concept of 'accounting as practice'.

The results of this research will be grounded on a consistent amount of data from different source (participant and non-participant observations, interviews, corporate documents), respecting the principle of triangulation. The analysis of the data is made through coding and analyzing the connections between categories. Works of this kind in management studies are well established, but rarely done given the difficulties in finding an adequate access to an organization and given the high time-consuming activities in which a researcher must be involved. This kind of research will thus provide 
to the academic environment a unique and innovative contribution.

\section{Reference list}

Malsch, B., Gendron, Y., Grazzini, F. (2011) “Investigating interdisciplinary translations: The influence of Pierre Bourdieu on accounting literature", Accounting, Auditing \& Accountability Journal, 24(2): 194-228.

Masquefa, B., Gallhofer, S., Haslam, J. (2016) “Developing appreciation of micro-organizational processes of accounting change and indicating pathways to more 'Enabling Accounting' in a micro-organizational domain of research and development", Critical Perspectives on Accounting. In press.

Quattrone, P., Hopper, T. (2005) "A 'time-space odyssey': management control systems in two multinational organisations", Accounting, Organizations and Society, 30(7): 735-764.

Soin, K., Seal, W., Cullen, J. (2002) "ABC and organizational change: an institutional perspective", Management Accounting Research, 13(2): 249-271.

Whittington, R. (2006) “Completing the practice turn in strategy research", Organization studies, 27(5): 613-634. 